\title{
General Medicine, Open Access: A Wonderful 2016 Harvest and New Heights to Look Forward In 2017
}

\section{Mina T Kelleni*}

Department of Pharmacology, Faculty of Medicine, Minia University, Egypt

*Corresponding author: Mina T. Kelleni, Department of Pharmacology, Faculty of Medicine, Minia University, Egypt, Tel: (+20) 1200382422; E-mail: drthabetpharm@yahoo.com

Rec Date: December 2, 2016; Acc date: December 3, 2016; Pub date: December 5, 2016

Copyright: (C) 2016 Kelleni MT. This is an open-access article distributed under the terms of the Creative Commons Attribution License, which permits unrestricted use, distribution, and reproduction in any medium, provided the original author and source are credited.

Citation: Kelleni MT (2017) General Medicine, Open Access: A Wonderful 2016 Harvest and New Heights to Look Forward In 2017. Gen Med (Los Angeles) 5 1000e112. doi:10.4172/2327-5146.1000e112

\section{Editor's Note}

Gaining the trust of so many respectful authors from all over the world in a medical journal is a very tough job; maintaining this trust is a tougher yet a very interesting work as well. In 2016, General Medicine, open access kept the promise to represent a high quality diaspora of medical literature; it also gave the chance to introduce very novel ideas for the first time. In brief, I'll demonstrate a rapid synopsis of the amazing activity performed throughout the previous year in the journal. In the first issue of 2016, General Medicine, open access published papers to authors from Iran, KSA, India, and Morocco who discussed topics related to $\mathrm{H}$. pylori relation with ovarian and uterine abnormalities, quality risk assessment, post-operative hyponatremia as well as a perspective towards diabetes mellitus management and two peculiar case reports. In the second issue authors from Canada, Italy, Japan, Korea, USA, Turkey, Poland, and France among authors from previously mentioned countries have enriched the scientific medical literature discussing topics related to preventive medicine, anesthesia, post-operative fluid homeostasis and outcomes, oncologic detection techniques, community medicine, tropical medicine, stem cell therapy, andrology, dermatology as well as presenting interesting case studies. In the third issue, authors from Brazil, Germany, Chile, Taiwan, and
Egypt joined authors from previously mentioned countries and discussed topics related to orthopedics, respiratory medicine, pediatrics, nephrology, cardiology, gastroenterology, hepatology, ophthalmology, diabetes mellitus and bioinformatics among other important topics related to previously mentioned categories. In the fourth issue, authors from Spain and Singapore joined authors from previously mentioned countries and discussed topics related to psychotherapy, medical education, hematology, bariatric surgery, cardiothoracic surgery, nursing, and digestive endoscopy. In the fifth issue, authors from UK, Ethiopia, Greece, and China joined authors from previously mentioned countries and discussed topics related to public health, history of medicine, emergency medicine, intensive care medicine, neurosurgery and pharmacognosy added to topics related to previously mentioned categories. We, the family gathering the editorial board and wonderful administrative team, are very proud of your trust and we promise to do our best to keep the quality and to promote the diaspora that distinguish our journal. Indeed, we work faithfully in one teamwork spirit full of hope and we're looking forward to keep and promote the good work in 2017 thanks to your trust and continuous co-operation. 